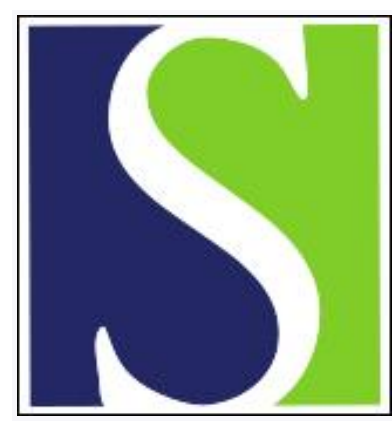

Scand J Work Environ Health 1989;15(4):265-270

https://doi.org/10.5271/sjweh.1853

Issue date: Aug 1989

\section{Cancer incidence among Danish stone workers.}

by Guenel P, Hojberg G, Lynge E

Affiliation: Danish Cancer Society, Copenhagen. 


\title{
Cancer incidence among Danish stone workers
}

\author{
by Pascal Guénel, ${ }^{1,2}$ Gunvor Højberg, ${ }^{3}$ Elsebeth Lynge ${ }^{1}$
}

\begin{abstract}
GUÉNEL P, HØJBERG G, LYNGE E. Cancer incidence among Danish stone workers. Scand $J$ Work Environ Health 1989;15:265-270. The lung cancer incidence of 2071 Danish stone workers was followed for a 42-year period. The expected numbers of cancer cases were based on the incidence rates for all Danish men after adjustment for region, and the data were analyzed separately for skilled and unskilled stone workers. The standardized incidence ratio (SIR) for lung cancer was 200 (44 observed, 22.0 expected) for all skilled stone workers, 808 ( 7 observed, 0.9 expected) for skilled sandstone cutters in Copenhagen, 119 (8 observed, 6.5 expected) for skilled granite cutters in Bornholm, 181 ( 24 observed, 13.2 expected) for all unskilled stone workers, 246 (17 observed, 6.9 expected) for unskilled workers in the road and building material industry, and 111 (7 observed, 6.3 expected) for unskilled workers in the stonecutting industry. Smoking was unlikely alone to explain the excess risk, and the available data on levels of exposure in the Danish stone industry point to a possible dose-response relationship between exposure to respirable silica dust and the incidence of lung cancer.
\end{abstract}

Key terms: follow-up study, lung cancer, neoplasms, silica, stone industry.

In 1987, the International Agency for Research on Cancer concluded that there is sufficient evidence for the carcinogenicity of crystalline silica in experimental animals and limited evidence for a corresponding effect in humans (1). An excess risk for lung cancer has been found in several occupational groups exposed to silica dust (2). Most of these groups are, however, also exposed to known lung carcinogens in the workplace, such as polycyclic aromatic hydrocarbons $(\mathrm{PAH})$ in foundries and radon daughters in mines. Data are therefore needed on the occurrence of lung cancer in populations with exposure to silica dust without concomitant exposure to known lung carcinogens in an occupational setting. Stonecutters are of particular interest. Register data from a 10 -year follow-up of the cancer incidence recorded for the Danish population in the 1970 census showed a relative risk for lung cancer of $2.10(95 \% \mathrm{CI} 0.77-4.57)$ among skilled stonecutters and of $2.90(95 \%$ CI 1.17-5.98) among self-employed stonecutters (3). A cohort study with a larger group of persons and a longer follow-up period was undertaken to determine further the risk of lung cancer among Danish stonecutters.

The Danish stone industry can be divided into two parts, the stonecutting industry, which produces monuments from granite or sandstone, and the road and building material industry, in which granite and flint

\footnotetext{
1 Danish Cancer Society, Danish Cancer Registry, Copenhagen, Denmark.

2 Present address: National Institute for Health and Medical Research, Paris, France.

3 Danmarks Statistik, Copenhagen, Denmark.
}

Reprint requests to: Dr P Guénel, Institut National de la Santé et de la Recherche Médicale Unité, Inserm Unité 88, 91, Boulevard de l'Hôpital, F-75634 Paris Cedex 13, France. are crushed and sorted. Small stonecutting workshops are scattered throughout the country, whereas road and building material firms are located only where the raw material is. Bornholm is the only place in Denmark where granite rocks are found, and the island has therefore been a place of importance for the Danish stone industry.

The stonecutting industry mainly employs skilled workers, who carry out operations such as cutting, sawing, edging, grinding, or carving blocks of stone (eg, for tombstones). Skilled workers usually start in the trade at the age of 15 years and practice it for their entire worklife. Some unskilled workers are employed in the stonecutting industry, mainly producing curb stones by splitting stone blocks in open sheds. Unskilled workers are employed in the road and building material industry in operations such as stone block crushing and gravel sieving. Most unskilled workers are employed in the stone industry for short periods only.

Measurements of exposure to silica dust in the Danish stone industry, 1948-1980, were available in the archives of the Danish National Institute of Occupational Health. These data were retrieved, and the analysis has been reported separately (4). The analysis showed the highest exposure levels to be found in the road and building material industry, where the median exposure to respirable quartz in the 1970 s was 0.16 (range $0.02-12.7$ ) $\mathrm{mg} / \mathrm{m}^{3}$, whereas the equivalent value for the stonecutting industry was 0.05 (range $0.02-0.57) \mathrm{mg} / \mathrm{m}^{3}$. The exposure levels were thus the highest in the part of the stone industry in which the employment periods were on the average the shortest. In the present study, workers were included both from the many small stonecutting workshops scattered throughout the country and from one road and building material company in Denmark. 


\section{Subjects and methods}

Different data sources are available in Denmark for identifying skilled workers because they have separate unions, their occupation is recorded in administrative registers, etc. Unskilled workers all belong to the same union, and their occupation is normally not recorded. In most cases unskilled workers from a given industry can therefore be identified only from employer records. Many of the small road and building material companies in Denmark have been closed down, and complete records going back to the 1940s could only be found in one company.

Table 1 presents the data sources in the study. Stone workers from Bornholm were identified from four sources. The 1940 and 1950 census forms from the relevant municipalities were used to retrieve the name, date of birth, address, and job title of any stone worker or any worker in the stonecutting industry. The 1938 address book of Bornholm was used to identify the name and address of all residents listed as stone workers. Employer records were used to identify employees from the road and building material company "Superfos" for the period 1941-1970, and employees from the relatively big stonecutting company "De forenede Granitbrud," where records were unfortunately only available for the period 1957-1970.

Two sources were used to identify stone workers from other parts of Denmark. Trade union lists were available for stonecutters in Copenhagen, Sealand, and Jutland for different time periods, as listed in table 1. These lists included names and addresses and, for Copenhagen, information on the main stone material used (granite or sandstone). Self-employed stonecutters were identified from the annual lists published by the stonecutter association for the period 1941-1978. These lists included information on the name and address of the workplace.

Table 1. Number of men in the cohort by data source and status as traced or untraced.

\begin{tabular}{|c|c|c|c|c|}
\hline Source & $\begin{array}{c}\text { Year of } \\
\text { identification }\end{array}$ & Traced & Untraced & $\begin{array}{c}\text { Untraced } \\
\text { percentage } \\
\text { of total }\end{array}$ \\
\hline \multicolumn{5}{|l|}{ Bornholm } \\
\hline $\begin{array}{l}\text { Census } \\
\text { Address book } \\
\text { Superfos } \\
\text { De Forenede } \\
\text { Granitbrud }\end{array}$ & $\begin{array}{l}1940,1950 \\
1938 \\
1941-1970 \\
1957-1970\end{array}$ & $\begin{array}{l}735 \\
319 \\
678 \\
\\
114\end{array}$ & $\begin{array}{r}18 \\
14 \\
27 \\
\\
7\end{array}$ & $\begin{array}{l}2.4 \\
4.2 \\
3.8 \\
\\
5.8\end{array}$ \\
\hline \multicolumn{5}{|l|}{$\begin{array}{l}\text { Other parts } \\
\text { of Denmark }\end{array}$} \\
\hline \multicolumn{5}{|l|}{ Union lists } \\
\hline $\begin{array}{l}\text { Copenhagen } \\
\text { Sealand } \\
\text { Jutland }\end{array}$ & $\begin{array}{l}1931-1965 \\
1950 \\
1960-1970\end{array}$ & $\begin{array}{r}172 \\
52 \\
202\end{array}$ & $\begin{array}{r}14 \\
4 \\
7\end{array}$ & $\begin{array}{l}7.5 \\
7.1 \\
3.3\end{array}$ \\
\hline \multicolumn{5}{|l|}{ All Denmark } \\
\hline $\begin{array}{l}\text { Lists of } \\
\text { self-employed }\end{array}$ & $1941-1978$ & 277 & 18 & 6.1 \\
\hline Total $^{\mathrm{a}}$ & $1931-1978$ & 2071 & 104 & 4.8 \\
\hline
\end{tabular}

Date of birth was available in only two of the six data sources, ie, in the 1940 and 1950 census forms and in some of the Superfos records. For most of the identified stone workers the date of birth was therefore provided by the municipality population registers on the basis of name, address, job title, and time of identification. A unique personal identification number has been given to every resident in Denmark since 1 April 1968. If this number was available for a given person, the possible date of death and emigration was traced through the Central Population Register. For the remaining one-third of the cohort the tracing of death and emigration was carried out manually in the municipality population registers. Any stone worker was included in the cohort if he was alive on 1 January 1943 or born later and if he was below the age of 65 years at the time he was first identified in one of the six data sources. A total of 2175 stone workers fulfilled these criteria, and $95 \%$ were successfully traced. Thus a total of 2071 stone workers was included in the study. The identification of cancer cases in the cohort was carried out by linkage with the Danish Cancer Registry, which keeps records of all cancer cases diagnosed in Denmark since 1943.

When an individual was identified for the first time in a list before 1943, he contributed to the person-years from 1 January 1943. When the date of first identification occurred later, his contribution to the personyears started at the date of first identification. The date of first identification was not necessarily the date of first employment, since most of the data sources used in the present study were cross-sectional listings. The two dates were identical only for workers identified from employer records. Individual follow-up was terminated at the date of death, date of emigration, date of cancer diagnosis, or on 31 December 1984.

Person-years were calculated by five-year calendar periods and five-year age groups with a person-year computer program (5) developed in the Danish Cancer Registry. The expected numbers of cancer cases were computed with the Danish national incidence rates for men for corresponding calendar periods and age groups. Standar dized incidence ratio (SIR) values were calculated by dividing the observed number of cases with the expected number, and the $95 \%$ confidence intervals $(95 \% \mathrm{CI})$ for the SIR values were calculated on the assumption that the observed number of cases followed a Poisson distribution and that the expected number was a constant.

Smoking data were not available for the cohort members. An attempt was made to control for this factor in two ways. First, the lung cancer incidence varied in Denmark in the 1970s primarily due to regional differences in smoking habits, from a relative risk, compared to the national average, of 0.40 for the small population of Bornholm ( 24000 men) to a relative risk of 1.66 for the population in the Copenhagen municipality (264 000 men) and 0.84 for the rest of Denmark (1 856000 men) (6). Adjustment for region was made 
by multiplying the expected number of cancer cases with the relative risk for the region. Standardization with age- and time-specific incidence rates for regions was not made, as the rates for Bornholm were unstable due to the small numbers. Use of time-specific relative risks for regions was found to change the adjustment only slightly, and the data have not been reported. Second, the incidence of bladder cancer in the cohort was analyzed in parallel to the incidence of lung cancer, as bladder cancer is a relatively frequent disease and etiologically related to smoking but probably not to silica dust exposure. Migrations within Denmark after the date of first identification were not recorded, but such migrations are of quantitatively minor importance.

\section{Results}

The analysis of cancer incidence in the cohort was carried out separately for the skilled and unskilled workers because of the differences in work tasks and in the length of employment. Of the 2071 stone workers, 1081 were skilled workers (479 from Bornholm, 199 from Copenhagen, and 403 from other parts of Denmark), and 990 were unskilled workers (all of them from Bornholm, 581 being from the road and building material industry and 409 being from the stonecutting industry). The individual length of follow-up averaged 30 years in each group, except for skilled workers in other parts of Denmark, for whom the mean period of follow-up was 24 years.

Skilled workers. A total of 211 cancer cases was observed for the cohort of skilled workers, 159.3 cases being expected on the basis of national incidence rates (SIR 132, 95\% CI 115-151). Table 2 shows the observed and expected numbers for lung and bladder cancer among the skilled workers by region. When the national incidence rates were used for comparison, the SIR for lung cancer for all skilled workers was 138 , which was on the border of statistical significance (44 observed, 31.8 expected, $95 \%$ CI 100-189). When the expected numbers were adjusted for region, the SIR for lung cancer for all the skilled workers increased to the statistically significant value of 200 (44 observed, 22.0 expected, $95 \%$ CI 149-269). The unadjusted SIR for bladder cancer for all the skilled workers was 132 (17 observed, 13.0 expected, $95 \%$ CI 77-211). The regional adjustment changed this value only slightly. A statistically significant excess risk of lung cancer was observed in the adjusted figures for Copenhagen, for which the SIR was 306 (18 observed, 5.9 expected, $95 \%$ CI 181-482), and for the other parts of Denmark (except Bornholm), for which the SIR was 192 (18 observed, 9.4 expected, $95 \%$ CI 167-303). The adjusted SIR for lung cancer among the skilled workers from Bornholm was only slightly increased with an SIR of 119 (8 observed, 6.7 expected, $95 \%$ CI
$51-235)$. An adjusted SIR of 211 for bladder cancer was observed for the skilled workers in Copenhagen. This figure was, however, based on a small number of observed cases, and none of the SIR values for bladder cancer among the skilled workers differed significantly from 100 .

Table 3 shows the observed and expected numbers of lung cancer among the skilled stonecutters from

Table 2. Observed and expected numbers of lung and bladder cancer among the skilled workers by region. (SIR =standardized incidence ratio, $95 \% \mathrm{Cl}=$ confidence interval)

\begin{tabular}{|c|c|c|c|c|}
\hline Region & $\begin{array}{l}\text { Ob- } \\
\text { served }\end{array}$ & $\begin{array}{c}\text { Ex- } \\
\text { pected }\end{array}$ & SIR & $95 \% \mathrm{Cl}$ \\
\hline \multicolumn{5}{|l|}{ Bornholm } \\
\hline \multicolumn{5}{|l|}{ Lung } \\
\hline $\begin{array}{l}\text { Unadjusted } \\
\text { Adjusted }^{\mathrm{b}}\end{array}$ & $\begin{array}{l}8 \\
8\end{array}$ & $\begin{array}{r}16.7 \\
6.7\end{array}$ & $\begin{array}{r}48 \\
119\end{array}$ & $\begin{array}{l}21-94 \\
51-235\end{array}$ \\
\hline \multicolumn{5}{|l|}{ Bladder } \\
\hline $\begin{array}{l}\text { Unadjusteda } \\
\text { Adjusted }\end{array}$ & $\begin{array}{l}8 \\
8\end{array}$ & $\begin{array}{l}6.9 \\
6.4\end{array}$ & $\begin{array}{l}115 \\
125\end{array}$ & $\begin{array}{l}50-227 \\
54-247\end{array}$ \\
\hline \multicolumn{5}{|l|}{ Copenhagen } \\
\hline \multicolumn{5}{|l|}{ Lung } \\
\hline $\begin{array}{l}\text { Unadjusteda } \\
\text { Adjusted }^{\mathrm{b}}\end{array}$ & $\begin{array}{l}18 \\
18\end{array}$ & $\begin{array}{l}3.9 \\
5.9\end{array}$ & $\begin{array}{l}465 \\
306\end{array}$ & $\begin{array}{l}274-729 \\
181-482\end{array}$ \\
\hline \multicolumn{5}{|l|}{ Bladder } \\
\hline $\begin{array}{l}\text { Unadjusted }^{\mathrm{a}} \\
\text { Adjusted }^{\mathrm{b}}\end{array}$ & $\begin{array}{l}4 \\
4\end{array}$ & $\begin{array}{l}1.4 \\
1.9\end{array}$ & $\begin{array}{l}292 \\
211\end{array}$ & $\begin{array}{l}80-747 \\
57-539\end{array}$ \\
\hline \multicolumn{5}{|l|}{ Other Denmark } \\
\hline \multicolumn{5}{|l|}{ Lung } \\
\hline $\begin{array}{l}\text { Unadjusteda } \\
\text { Adjusted }^{\mathrm{b}}\end{array}$ & $\begin{array}{l}18 \\
18\end{array}$ & $\begin{array}{r}11.2 \\
9.4\end{array}$ & $\begin{array}{l}161 \\
192\end{array}$ & $\begin{array}{r}95-254 \\
167-303\end{array}$ \\
\hline \multicolumn{5}{|l|}{ Bladder } \\
\hline $\begin{array}{l}\text { Unadjusted } \\
\text { Adjusted }^{\mathrm{a}}\end{array}$ & $\begin{array}{l}5 \\
5\end{array}$ & $\begin{array}{l}4.6 \\
4.0\end{array}$ & $\begin{array}{l}109 \\
125\end{array}$ & $\begin{array}{l}35-254 \\
40-292\end{array}$ \\
\hline \multicolumn{5}{|l|}{ All Denmark } \\
\hline \multicolumn{5}{|l|}{ Lung } \\
\hline $\begin{array}{l}\text { Unadjusted } \\
\text { Adjusted }\end{array}$ & $\begin{array}{l}44 \\
44\end{array}$ & $\begin{array}{l}31.8 \\
22.0\end{array}$ & $\begin{array}{l}138 \\
200\end{array}$ & $\begin{array}{l}100-189 \\
149-269\end{array}$ \\
\hline \multicolumn{5}{|l|}{ Bladder } \\
\hline $\begin{array}{l}\text { Unadjusted } \\
\text { Adjusted }\end{array}$ & $\begin{array}{l}17 \\
17\end{array}$ & $\begin{array}{l}13.0 \\
12.3\end{array}$ & $\begin{array}{l}132 \\
138\end{array}$ & $\begin{array}{l}77-211 \\
80-221\end{array}$ \\
\hline
\end{tabular}

a Unadjusted = based on national incidence rates.

b Adjusted $=$ based on national incidence rates adjusted for region. (See the text.)

Table 3. Observed and expected numbers of lung cancer among the skilled workers in Copenhagen by type of stone material, time of first identification. (SIR = standardized incidence ratio adjusted for Copenhagen, $95 \% \mathrm{CI}=$ confidence interval)

\begin{tabular}{lrccc}
\hline & $\begin{array}{c}\text { Ob- } \\
\text { served pected }\end{array}$ & SIR & $95 \% \mathrm{Cl}$ \\
\cline { 2 - 5 } Stone material & 7 & 0.9 & 808 & $323-1657$ \\
$\quad$ Sandstone & 11 & 2.7 & 404 & $202-723$ \\
$\quad$ Granite & 0 & 2.3 & - & - \\
$\quad$ Otherlunknown & & & & \\
Time of first & & & & \\
identification & 14 & 3.9 & 357 & $195-599$ \\
$\quad$ Before 1940 & 4 & 1.8 & 221 & $60-566$ \\
$\quad$ After 1940 & 18 & 5.9 & 306 & $181-482$ \\
All Copenhagen & & & & \\
\hline
\end{tabular}


Copenhagen, for whom the main stone material used was known for most of the workers. From a total of 18 lung cancer cases observed in Copenhagen, 11 were granite workers (adjusted expected number 2.7) and seven were sandstone workers (adjusted expected number 0.9). Fourteen lung cancer cases were identified before 1940 ( 3.9 expected), and four were identified after this date (1.8 expected).

Unskilled workers. All the unskilled workers came from the Bornholm area. A total of 155 cancer cases were observed in this group, for which 144.3 cases were expected on the basis of national incidence rates (SIR $145,95 \%$ CI 123-170). Table 4 shows the observed and expected numbers for lung and bladder cancer among this group. A total of 24 lung cancer cases was observed, the SIR being 72 (95\% CI 46-108) when the national rates were used for comparison. The SIR increased to the statistically significant value of 181 (95\% CI 116-270) when adjustment was made for region. The SIR for bladder cancer was significantly below 100 in both comparisons.

Table 4 also shows the SIR for lung and bladder cancer among the unskilled workers by industry. When the adjusted expected numbers were used for comparison, the unskilled workers in the stonecutting industry had an SIR of 111 (7 observed, 6.3 expected, $95 \%$

Table 4. Observed and expected numbers of lung and bladder cancer among the unskilled workers by industry. (SIR = standardized incidence ratio, $95 \% \mathrm{Cl}=$ confidence interval)

\begin{tabular}{|c|c|c|c|c|}
\hline & $\begin{array}{l}\text { Ob- } \\
\text { served }\end{array}$ & $\begin{array}{c}\text { Ex- } \\
\text { pected }\end{array}$ & SIR & $95 \% \mathrm{Cl}$ \\
\hline \multicolumn{5}{|l|}{$\begin{array}{l}\text { Stonecutting } \\
\text { industry workers }\end{array}$} \\
\hline \multicolumn{5}{|l|}{ Lung } \\
\hline $\begin{array}{l}\text { Unadjusted } \\
\text { Adjusted }\end{array}$ & $\begin{array}{l}7 \\
7\end{array}$ & $\begin{array}{r}15.8 \\
6.3\end{array}$ & $\begin{array}{r}44 \\
111\end{array}$ & $\begin{array}{l}18-92 \\
45-229\end{array}$ \\
\hline \multicolumn{5}{|l|}{ Bladder } \\
\hline $\begin{array}{l}\text { Unadjusted } \\
\text { Adjusted }\end{array}$ & $\begin{array}{l}0 \\
0\end{array}$ & $\begin{array}{l}6.2 \\
5.7\end{array}$ & $\dot{.}$ & . \\
\hline \multicolumn{5}{|l|}{$\begin{array}{l}\text { Road material } \\
\text { industry workers }\end{array}$} \\
\hline \multicolumn{5}{|l|}{ Lung } \\
\hline $\begin{array}{l}\text { Unadjusted } \\
\text { Adjusted }^{\mathrm{a}}\end{array}$ & $\begin{array}{l}17 \\
17\end{array}$ & $\begin{array}{r}17.3 \\
6.9\end{array}$ & $\begin{array}{r}99 \\
246\end{array}$ & $\begin{array}{r}57-158 \\
143-394\end{array}$ \\
\hline \multicolumn{5}{|l|}{ Bladder } \\
\hline $\begin{array}{l}\text { Unadjusted } \\
\text { Adjusted }\end{array}$ & $\begin{array}{l}5 \\
5\end{array}$ & $\begin{array}{l}6.4 \\
5.9\end{array}$ & $\begin{array}{l}78 \\
84\end{array}$ & $\begin{array}{l}25-182 \\
27-198\end{array}$ \\
\hline \multicolumn{4}{|c|}{ Total (all Bornholm) } & Lung \\
\hline $\begin{array}{l}\text { Unadjusted a } \\
\text { Adjusted }\end{array}$ & $\begin{array}{l}24 \\
24\end{array}$ & $\begin{array}{l}33.1 \\
13.2\end{array}$ & $\begin{array}{r}72 \\
181\end{array}$ & $\begin{array}{r}46-108 \\
116-270\end{array}$ \\
\hline \multicolumn{5}{|l|}{ Bladder } \\
\hline $\begin{array}{l}\text { Unadjusted } \\
\text { Adjusted }\end{array}$ & $\begin{array}{l}5 \\
5\end{array}$ & $\begin{array}{l}12.6 \\
11.6\end{array}$ & $\begin{array}{l}40 \\
43\end{array}$ & $\begin{array}{l}13-93 \\
14-101\end{array}$ \\
\hline
\end{tabular}

a Unadjusted $=$ based on national incidence rates .

b Adjusted = based on national incidence rates adjusted for region. (See the text.)
CI 45-229) for lung cancer, whereas the unskilled workers in the road and building material industry had a statistically significantly increased SIR of 246 (17 observed, 6.9 expected, $95 \%$ CI 143-394). Among the unskilled workers all the cases of bladder cancer were observed among the workers from the road and building material industry, but the SIR for bladder cancer was below 100 in this group.

\section{Discussion}

The study showed an excess risk of lung cancer among the skilled stonecutters from Copenhagen and from other parts of Denmark with SIR values, adjusted for region, of 306 and 192, respectively. The lung cancer risk of the skilled stonecutters from Bornholm was only marginally increased with an adjusted SIR of 119. All the subcohorts were observed with a long latency period since time of first exposure as the follow-up periods averaged more than 20 years. The few available exposure measurements from the stonecutting industry from the 1970s showed a median exposure to respirable quartz of $0.06 \mathrm{mg} / \mathrm{m}^{3}$ for Copenhagen compared to $0.03 \mathrm{mg} / \mathrm{m}^{3}$ for other parts of Denmark (except Bornholm). Unfortunately, no measurements were available from the stonecutting industry in Bornholm.

The excess risk of lung cancer in Copenhagen was higher for those workers identified before 1940 than for those identified later. Mechanical ventilation was introduced in the stonecutting industry for cutting with pneumatic tools in the early 1950s (7) and for handcutting in the late 1950s (8). The first list of Copenhagen workers dated back to 1931 , and these workers were therefore expected, on the average, to have experienced higher exposure levels than skilled workers from the other parts of Denmark, where the identification started about 10 years later.

In Copenhagen, the excess risk of lung cancer was particularly high for stonecutters known to have worked with sandstone. Only 47 men belonged to this group, of whom seven developed lung cancer during the follow-up period. In 1938, a radiographic examination was made of 114 Copenhagen stonecutters who had worked at least five years in this occupation. Silicosis was found in $56 \%$ (10 of 18) of the sandstone cutters, in $14 \%$ (9 of 65 ) of the granite cutters, and in $23 \%$ ( 7 of 31 ) of the men cutting both minerals (9). Another examination of stonecutters was made in 1952; these workers were mainly from Copenhagen and mainly above the age of 45 years. Silicosis was found in $53 \%$ (10 of 19) of the sandstone cutters and in $22 \%$ (10 of 46) of the granite cutters (10). The Copenhagen sandstone cutters, whose lung cancer risk during the follow-up period was eight times higher than the risk of the general population, thus had a heavy burden of silicosis in their worklife.

The unskilled workers were all identified in Bornholm and had been exposed mainly to granite dust. The results for lung cancer differed between the work- 
ers from the stonecutting industry, for which the adjusted SIR was 111, and the workers from the road and building material industry, for which the adjusted SIR was 246 . No exposure measurements were available from the stonecutting industry in Bornholm. The unskilled workers in the stonecutting industry worked predominantly in open sheds and produced curb stones by splitting stone blocks. Exposure measurements were available from the Danish road and building material industry, and in the 1970 s the highest median exposure to respirable quartz was $0.29 \mathrm{mg} / \mathrm{m}^{3}$; it was recorded for Bornholm. The work operations were not given in the employer records, and we were therefore not able to identify those who worked in the dusty crushing operations (4).

A radiographic examination was made of 300 Bornholm stone workers in 1935 . Silicosis was found in $22 \%$ (60 of 278 qualified radiographs) of the workers. The men were recorded to work predominantly in open air with different processes. Crushing was done indoors and was found to be associated with a considerably higher risk of silicosis than other processes (11). A survey in 1953 of skilled granite cutters from Bornholm showed $47 \%$ (23 of 49) to have silicosis. Unfortunately, no information was available on the age and work processes of the men in this 1953 survey (12). From 1958-1986 silicosis was reported as the primary cause of death on only six death certificates from Bornholm (Knud Juel, personal communication, 1988).

Tobacco consumption could not be controlled for in the analysis, and the bladder cancer incidence was therefore analyzed in parallel to that of lung cancer. The adjusted standardized mortality ratio for lung cancer in the total cohort was 193, whereas the adjusted standardized mortality ratio for bladder cancer was 92 , and an excess use of tobacco alone is therefore unlikely to explain the excess risk of lung cancer. The cohort data could not be analyzed separately for stone workers with and without silicosis, as a reliable register of silicosis patients was not available for the study period.

In the Vermont stone quarries of the United States dust control was installed in the granite sheds in 1937-1940 (13). The precontrol dust exposure level to respirable silica was estimated to be $0.37 \mathrm{mg} / \mathrm{m}^{3}$ for stonecutters in comparison to an estimated postcontrol dust level of $0.07 \mathrm{mg} / \mathrm{m}^{3}$. Dust controls were installed in the quarries themselves in 1950. A proportionate mortality study covered 1023 deceased men identified from records from the periodic radiographic examinations. The men who had work experience in the Vermont stone industry from I January 1952 through 1 July 1978 had been employed for at least one year and had died prior to 1 July 1978. The subjects were divided into two groups on the basis of entry into the industry before and after the installation of dust control. The proportionate mortality ratio based on national rates for lung cancer was 1.1 for the precontrol group and 1.4 for the postcontrol group.
It is difficult to interpret the figures for the first group, as these men were survivors from the precontrol period and were still active in the industry in 1952-1978.

A proportionate mortality study covered those members of a granite cutters union for whom death benefits had been paid in the period 1948-1982 in the United States (14). A total of 2274 deaths was identified, one-third of the decedents being workers from the Vermont granite sheds. Death certificates were obtained for 1911 of the deaths. The proportionate mortality ratio for lung cancer based on national rates was 1.19 (95\% CI 0.97-1.46). In this study death certificates were traced for $84 \%$ of the deaths, which occurred mainly among workers who had had many years of good standing in the union and had had a next-of-kin to claim for the death benefit. These restrictions in the study design complicate the interpretation of the results.

A cohort study from quarries and processing yards from three regions of Finland covered 1026 workers hired for at least three months in $1941-1970(15,16)$. They were all traced and followed to 1981. The exposure levels to respirable quartz were measured in $1970-1972$. The observed ranges were $0.3-4.2 \mathrm{mg} / \mathrm{m}^{3}$ for drilling, $0.2-4.9 \mathrm{mg} / \mathrm{m}^{3}$ for block surfacing, and $0.02-3.6 \mathrm{mg} / \mathrm{m}^{3}$ for other work processes. In 1970 1972 the smoking habits of granite workers were similar to those of Finnish men. A total of 22 lung cancer deaths were observed in the cohort compared with 17.1 expected deaths based on rates for Finnish men in general. A significant excess risk for lung cancer was observed for workers with at least 15 years since entry into granite work (standardized mortality ratio 221).

Differences in the study design make a comparison between the American studies and the Danish study difficult. In Finland, the work processes included operations carried out both by workers in the Danish road and building material industry (quarrying, crushing) and by workers in the stonecutting industry (block processing). In the 1970 s some work processes entailed higher levels of exposure to respirable quartz in Finland (geometric mean $1.47 \mathrm{mg} / \mathrm{m}^{3}$ and $0.82 \mathrm{mg} / \mathrm{m}^{3}$ for drilling and block surfacing, respectively) than in Denmark (geometric mean $0.20 \mathrm{mg} / \mathrm{m}^{3}$ and $0.11 \mathrm{mg} / \mathrm{m}^{3}$ ). An analysis by latency period was not made in Denmark (the data sources being mainly cross-sectional listings) as it was in Finland. However, the long followup period in the present study allowed the majority of cancer cases potentially caused by silica dust exposure to be revealed.

Skilled stonecutters, particularly sandstone cutters, from Copenhagen, unskilled workers from the road and building material industry in Bornholm, and skilled stonecutters from other parts of Denmark have experienced an excess risk of lung cancer over the past 40 years. For those groups with the highest risk of lung cancer, there was also evidence of high exposure to silica dust, including a high prevalence of silicosis (eg, 
sandstone workers from Copenhagen), high exposure to quartz in industrial hygiene measurements (eg, from the road and building material industry in Bornholm), and an absence of ventilation at the workplace (eg, for workers identified before 1950 in Copenhagen).

The unskilled workers from the stonecutting industry and skilled stonecutters from Bornholm did not share the excess risk of lung cancer. No exposure measurements were available for the stonecutting industry in Bornholm. However, the outdoor operations carried out by the unskilled workers in the stonecutting industry may have entailed relatively low exposure levels.

The stone workers in this study have not been exposed to known lung carcinogens at the workplace, and the results of the study therefore point to a possible dose-response relationship between lung cancer and exposure to respirable silica dust.

\section{Acknowledgments}

We are indebted to Dr S Mikkelsen and Dr T Skov for their comments on the manuscript. Mortality data were provided from the death register of the Danish Institute of Clinical Epidemiology by Dr K Juel. Ms $L$ Mikkelsen and Ms P Neijendam assisted with the data collection. The study was supported by the Commission of the European Communities, grant ECI-1531-B7210-DK.

\section{References}

1. International Agency for Research on Cancer. Overall evaluations of carcinogenicity: an updating of IARC monographs volumes 1 to 42. Lyon: International Agency for Research on Cancer, 1987. (Monographs on the evaluation of carcinogenic risks to humans; suppl 7.)

2. International Agency for Research on Cancer. Silica and some silicates. Lyon: Iniernational Agency for Research on Cancer, 1987:39-143. (Monographs on the evalua- tion of the carcinogenic risk of chemicals to humans; vol 42).

3. Lynge E, Kurppa K, Kristofersen L, Malker H, Sauli $H$. Silica dust and lung cancer: results from the Nordic occupational mortality and cancer incidence registers. J Natl Cancer Inst 1986;77:883-9.

4. Guénel P, Breum NO, Lynge E. Exposure to silica dust in the Danish stone industry. Scand J Work Environ Health 1989;15:147-53.

5. Breslow NE, Day NE. Statistical methods in cancer research; vol 2. Lyon: International Agency for Research on Cancer, 1987:360.

6. Carstensen B, Jensen OM. Atlas of cancer incidence in Denmark 1970 - 79. Copenhagen: Danish Cancer Registry and Environmental Protection Agency, 1986.

7. Grage K. Støvplagen [The dust problem]. Stenhuggertidende 1953;36:53-4.

8. Anonymous. Udsugningen [Ventilation] [Editorial]. Stenhuggertidende 1955;38:20-2.

9. Arbejdstilsynet. Beretning om Arbejds- og Fabrikstilsynets virksomhed i året 1938 [Annual report on the National Labour Inspection 1938]. Copenhagen: Arbejdstilsynet, 1939.

10. Arbejdstilsynet. Beretning om Arbejds- og Fabrikstilsynets virksomhed $\mathrm{i}$ året 1952 [Annual report on the $\mathrm{Na}$ tional Labour Inspection 1952]. Copenhagen: Arbejdstilsynet, 1953.

11. Arbejdstilsynet. Beretning om Arbejds- og Fabrikstilsynets virksomhed i året 1935 [Annual report on the $\mathrm{Na}$ tional Labour Inspection 1935]. Copenhagen: Arbejdstilsynet, 1936.

12. Arbejdstilsynet. Beretning om Arbejds- og Fabrikstilsynets virksomhed $\mathrm{i}$ året 1953 [Annual report on the National Labour Inspection 1953]. Copenhagen: Arbejdstilsynet, 1954.

13. Davis LK, Wegman DH, Monson RR, Froines J. Mortality experience of Vermont granite workers. Am J Ind Med 1983;4:705-23.

14. Steenland K, Beaumont J. A proportionate mortality study of granite cutters. Am J Ind Med 1986;9:189-201.

15. Koskela R-S, Klockars M, Järvinen E, Kolari PJ, Rossi A. Mortality and disability among granite workers. Scand J Work Environ Health 1987;13:18-25.

16. Koskela R-S, Klockars M, Järvinen E, Kolari PJ, Rossi A. Cancer mortality of granite workers. Scand J Work Environ Health $1987 ; 13: 26-31$.

Received for publication: 12 December 1988 